\title{
POTENSI MODAL SOSIAL PADA BUDAYA LOKAL \\ DALAM PEMBANGUNAN DAERAH
}

\section{Oleh : Prof. Dr. Abu Hamid}

Pembahasan tema ini akan mengantar kita pada suatu pengertian tantang jaringan hubungan antar individu dalam masyarakat dan jaringan hubungan antar kelompok. Jaringan-jaringan itu dibimbing oleh suatu norma atau aturan, agar jaringan tersebut teratur dan terarah pada tujuan yang dikehendaki oleh kelompok Sosial menurut kebutuhan dan kepentingannya. Dalam norma dan jaringan itu, terlihat interaksi Sosial dan kemitraan yang saling mengukuhkan dan menguntungkan. Disinilah pentingnya modal Sosial disadari kegunaannya dan berpotensi mengantarkan manusia melakukan sector-sektor kehidupannya.

Tenunan jaringan Sosial itu yang berpedoman pada aturan dan peraturan yang dibuatnya, maka tampak adanya system-sistem yang pada bentuknya yang lebih abstrak, adalah sebuah struktur Sosial. Jaringan-jaringan kerja dengan aturan tertentu, biasanya berwujud pada sebuah lembaga Sosial. Dalam lembaga terjadi tindakan Sosial dan interaksi antar individu dan kelompok untuk memenuhi harapan, kebutuhan, kepentingan dan tujuan lembaga. Dengan demikian, modal Sosial berisi lembagalembaga Sosial, etika Sosial dan etika lingkungan, sementara kearifan local merupakan bagian sempit dari modal Sosial, sedang etos Sosial merupakan sifat, sikap, watak dan karakter Sosial yang bersesuai dengan world vieuw masyarakat local tersebut.

Modal Sosial harus dipelajari bersama dengan modal budaya (cultural capital), oleh karena keduanya saling berkaitan. Wadah kebudayaan adalah masyarakat, sering dipelajari dengan satu istilah yaitu Sosial budaya. Dimensi kebudayaan dapat dilihat dari berbagai segi, oleh karena ia diciptakan dan disebarkan oleh manusia. Orang tidak pernah melihat gaya berat, begitu pula orang tidak pernah melihat kebudayaan dan yang tampak adalah perilaku (behaviour) saling interaksi dengan sesamanya menurut aturan tertentu yang menjadi tradisi budaya (culture tradition), sesuai warisan budaya lokal yang mereka terima dari pendahulunya. Tradisi budaya ini dimodifikasi sedemikian rupa sesuai dengan kebutuhan zaman dan kondisi lingkungannya. Kebudayaan itulah, manusia melakukan dan menjalani kehidupan ini dengan menafsirkan pelbagai pengalaman hidup yang dialaminya. Warga masyarakat melakukan segala macam kerja pada lapangan hidupnya, konsep dan resep kelompoknya merupakan kearifan budaya dan dari padanya digunakan mencipta dan berkreasi.

Wujud kebudayaan harus dipahami sebagai suatu system penetahuan, gagasan dan kepercayaan yang dimiliki oleh suatu masyarakat. Fungsi dan system pengetahuan ini, memberi pedoman bagi masyarakat dalam hal bersikap dan berprilaku atas kontaknya dengan lingkungan alam dan Sosial dimana mereka berada. Betapapun modal Sosial, dikendali oleh sistem pengetahuan, modal budaya yang dimiliki oleh masyarakat merupakan kekuatan abstrak yang mampu memaksa dan mengarahkan penduduknya untuk berperilaku atas kontaknya dengan lingkungan alam dan Sosial di mana mereka berada. Betapa pun modal Sosial ini, dikendali oleh sistem pengetahuan, modal budaya yang dimiliki oleh masyarakat merupakan kekuatan abstrak yang mampu memaksa dan mengarahkan pendukungnya untuk berperilaku sesuai sistem pengetahuan tersebut. 
Kebudayaan sebagai suatu sistem, dimiliki oleh anggota masyarakat melalui proses belajar, sejak ia lahir sampai ajal menjemputnya. Kebudayaan mengatur kehidupan kita setiap saat sadar atau tidak mengenai hal ini, memang ada tekanan untuk mengikuti dan membentuk prilaku kita sesuai apa yang telah diciptakan oleh pendahulu kita. Banyak lagi penjelasan tentang dimansi kebudayaan, seperti terlukis dalam buku C. Kluchhohn, berjudul Mirror For Man, The Relation Of Antrhoplogy to Modern Life, 1949:23-29. Pandangan seperti ini, melihat kebudayaan sebagai "warisan" yang tidak perlu diganggu, cukup mengikuti apa yang sudah ada, adalah suatu realitas yang sudah dicipta dan sudah dilembagakan.

Apabila kebudayaan dipandang sebagai warisan Sosial dan sebagiannya menjadi modal Sosial dengan segala yang tampak, berupa perilaku dan benda-benda produk, maka kegiatan penelitian terhadapnya tentunya ide yang sudah terbentuk dalam kelompok etnik. Masih berkisar pada pandangan ini dikatakan bahwa setiap kebudayaan merupakan susunan teknik-teknik adaptasi atau strategi terhadap ekosistem dalam memperoleh input dari luar. Starategi adaptif tersebut, lahir dari dalam masyarakat melalui lembaga yang berfungsi evaluatif, selektif, dan dinamik mengembangkan semua aspek-aspek kebudayaan dan memproduksi output berupa perilaku pada pemangku kebudayaan. Semua itu adalah hasil modal budaya yang didalamnya terdapat local knowlodge (pengetahuan local) bersama local wisdom (kearifan lokal), menjadi sumber perkembangan budaya secara luwes melalui proses tranformasi. Apabila ilmuan Sosial mengandalkan penelitian terhadap proses perubahan masyarakat dan kebudayaan, maka yang menjadi perhatian utama adalah perubahan bentuk, fungsi dan peranan dari yang lama kepada yang baru, berarti pembaharuan ide-ide, pergeseran perilaku dan nilai, perubahan fisik benda yang sudah ada atau yang sedang terjadi.

Dalam hubungan dengan pendapat, bahwa kebudayaan menimbulkan berbagai kebutuhan dan kepentingan serta menyediakan cara-cara untuk memenuhi kebutuhan tersebut. Selain kebutuhan primer, lebih besar biayanya adalah kebutuhan kebudayaan, seperti kebutuhan untuk gengsi Sosial, gaya hidup konsumtif dan penampilan mewah yang hedonistis beserta keinginan memperoleh prestise. Kebudayaan yang dilihat dari aspek waktu, bahwa ia memiliki pancaran sejarah, yaitu aspek sejarah masa lalu, biasanya dalam bentuk baru yang sudah mengalami seleksi, berkembang secara transformatif, akhirnya sampai pada kita. Penemuan dan invention baru, material dan ideologis serta sistem kepercayaan, dipersiapkan oleh kelompok sendiri. Akumulasi sejarah berbagai warisan Sosial, anak manusia yang lahir dari warisan tersebut melanjutkannya, biasanya dalam bentuk yang sudah disesuaikan dengan kondisi lingkungan dan kemajuan masyarakat.

\section{II}

Hampir semua unsur-unsur kehidupan ini sudah mengalami transformasi atas perubahan waktu, terjadinya penemuan baru dan adanya difusi unsur budaya asing dari luar. Menurut teori transformasi, bahwa beberapah unsur budaya gugur, karena tidak diperlukan lagi dan yang lainnya berlanjut terus dengan modifikasi tertentu. Unsur budaya yang gugur tersebut, adakalanya muncul kembali dengan konsep yang diperbaharui dan interpretasi yang baru pula. Sementara unsur yang berlanjut, karena gagasan dan nilai yang dikandungnya masih disadari pentingnya oleh sebagian anggota masyarakat. Transformasi bias membawa pembaharuan dan mungkin pula membawa kemerosotan, bila daya selektivitas kurang memadai.

Trasformasi tradisi, disebut demikian sejak kehidupan manusia tergantung atau ditentukan oleh alam, namun secara perlahan manusia mencipta dan memajukan kebudayaannya. Pewarisan 
budaya secara simbolis, secara tradisi lisan/tulisan, melalui kultus, ritus-ritus dan system kepercayaan, inilah yang dipelajari dan disadari oleh generasi masyarakat sekarang.

Pertanyaan yang muncul, apakah masih perlu dianut ajaran teori transformasi dalam keadaan masyarakat yang serba cepat dengan pengaruh ilmu pengetahuan dan teknologi canggih sekarang ini. Kondisi pemerintah dan kehidupan masyarakat telah mengalami perubahan mendasar yang tentunya berpengaruh pada budaya bangsa. Disamping perkembangan globalisasi dan modernisasi bidangbidang kehidupan, adalah konsekuensi pula yang berpengaruh terhadap kebudayaan.

Sudah lama Soedjatmoko telah memperingatkan pada kita suatu konsep "Revolusi Pengetahuan" yang harus digunakan secara konsekuen dari kemampuan ilmu pengetahuan untuk keperluan industrial. Inovasi dan invensi tidak lagi merupakan peristiwa insidentil, tetapi harus merupakan hasil pencarian ilmiah yang direncanakan dan diatur secara sadar. Pengerahan ilmu pengetahuan terhadap pengembangan masyarakat dan kebudayaan, seharusnya perantaraan Penelitian dan Pengembangan yang berorientasi penemuan. Temuan-temuan dari hasil pengerahan ilmu pengetahuan, bukan temuan reduplikasi atau semacam inventarisasi, melainkan sesuatu yang bias membawa perubahan dan pembaharuan, bila dimanfaatkan. Kenyataan sekarang, hampir semua instansi sudah memiliki lembaga penelitian, namun hasil penelitian tersebut belum diolah, apalagi dipergunakan.

Revolusi pengetahuan yang menyangkut masalah mendasar, sudah berjalan di Negara-negara maju atau Negara industri. Pengaruhnya terhadap kemajuan ekonomi industri, makin maju pesat dan makin kaya, sementara Negara berkembang terlambat dan makin miskin. Kemajuan negara maju tersebut, membangkitkan kekuatan Sosial sebagai akibat inovasi dan invensi atas pengerahan pengetahuan melalui penelitian berencana dan mendalam, telaj mengubah kehidupan manusia dalam paruh kedua abad ke-20. Dalam abad 21 ini Negara maju sudah melaju dengan pembuatan barangbarang sintetis, penyaringan air laut untuk keperluan irigasi, pengolahan bahan mentah menjadi bahan siap pakai dan kemajuan lainnya.

Konsep revolusi pengetahuan, rupanya ada kemiripan dengan konsep Thomas S. Khun, menganjurkan supaya berguru pada sejarah yang harus menjadi titik pangkal penelitian. Dikatakan bahwa perubahan mendalam haruslah melalui revolusi ilmiah, bahwa kemajuan ilmiah pertama-tama bersifat revolusioner, bertentangan dengan sebelumnya, bahwa ilmu pengetahuan maju secara komulatif. Khun adalah filosof yang berorientasi pada sejarah ilmu. Konsep pokok Khun ialah paradigma yang dapat ditafsir sebagai cara pandang terhadap dunia dan praktek ilmiah konkrit.

Marilah kita memakai revolusi pengetahuan atau ilmu pengetahuan yang sifatnya harus sistematis dan obyektif dalam aspek dinamis dan kreatif, yaitu kegiatan manusia kreatif, senantiasa mengejar pengetahuan baru, selalu tergugat jiwa dan pikirannya untuk menemukan sesuatu yang berguna, tanpa pernah puas atas semua temuannya itu. Semua komponen Sosial, diharapkan memiliki sikap demikian, terutama kaum intelek yang merasakan diri alumnus Perguruan Tinggi. Tidak terbatas pada kaum intelek saja, namun pemimpin organisasi dan tokoh masyarakat disyaratkan selalu bersikap sebagai pengejar dan penemu konsep baru. Apakah Pendidikan Tinggi perlu menjadi Research University atau membuat program studi Doktor peneliti? Semua ini merupakan alternative, tentunya disesuaikan dengan perkembangan dan kebutuhan, mengingat hambatan dan kerumitan perlu terlebih dahulu disingkirkan, seperti kondisi ekonomi dan politik. Tidak kalah pentingnya sebagai sebagai penghambat, adalah mentalitas bangsa, dalam arti kondisi kebudayaan itu sendiri. 
Inovasi unsur-unsur kehidupan kehidupan, berarti perubahan besar yang di-lakukan secara berencana dan secara bersama diterima sukarela, maka ketika itulah budaya inovasi sudah terjelma. Daya cipta dibangun dengan revolusi pengetahuan melalui penelitian dan pengembangan kreativitas terus menerus, sampai kegiatan itu dirasakan suatu kebutuhan, maka daya cipta sudah menjadi bagian kebudayaan. Inovasi dan daya cipta terkait satu dengan lainnya dan interplay antara keduanya yang mengajukan perkembangan kebudayaan.

\section{III}

Dalam masyarakat yang tidak menganut ajaran individualisme, kompetisi dianggap sesuatu yang negative, oleh karena kemajuan dan pembaharuan, dianggap tidak perlu berkompetitif, cukup bekerja bersama dan bergotong royong menghasilkan yang bermanfaat, itu sudah satu kemajuan. Maju bersama dan menikmati hasil bersama, tanpa perlu memilih sikap kompetitif. Rupanya paham ini menyamakan pengertian antara kompetisi dengan konflik. Pengalaman masa lalu ketika mulai digiatkan Pembangunan Lima Tahun pertama dan kedua, suasana masyarakat dikendalikan sedemikian rupa dengan konsep "stabilitas Sosial” sehingga kompetisi terpasung dan konflik terjaga tidak sampai mengganggu stabilitas.

Kopetisi adalah alamat masih adanya kehidupan, masih ada keinginan dan kebutuhan. Kompetisi adalah bagian dari gejala kemanusiaan, bahwa semenjak adanya kelompok manusia, di dalamnya terdapat kompetisi apakah menggejala atau tersembunyi.

Masyarakat Indonesia yang majemuk ini, terdiri atas berbagai suku bangsa dengan indentitas kebudayaan masing-masing. Setiap kebudayaan mempunyai intensitas, kuantitas, dan kualitas kompetisi yang berbeda dan cara pengendaliannya pula yang berbeda. Muncul pertanyaan, sejauh mana kompetisi setiap kebudayaan membawa kemajuan dan pembaharuan. Rupanya kebudayaan yang meletakan "harmonisasi" dalam hubungan Sosial dan lingkungan, kompetisi muncul sebagai akibat dari adanya asset Sosial yang diperlombakan memilikinya, sehingga yang tampil dipermukaan adalah memburu pemenuhan kebutuhan dan kepentingan, biasanya pemuasan diri atas benda-benda material dan posisi Sosial. Bukanlah kompetisi dalam arti persaingan pada kemampuan ilmu dan teknologi yang didukung oleh sikap rasioanal, kritis dan analistis.

Pra-syarat sikap kompetitif, harus menjunjung tinggi martabat manusia sebagai personal dengan nilai-nilai demokratis serta hak azasi seseorang, supaya dinamika hidup berlangsung secara dialektik. Dalam hal ini norma-norma Sosial dan nilai budaya menjadi control atas berlangsungnya kompetisi yang rasional dan sehat. Kompetisi diarahkan pada kegiatan produktif dan etos kerja tinggi, bebas dari sifat "kecemburuan Sosial" terhadap prestasi yang dicapai oleh seseorang. Sementara kebudayaan yang dimiliki oleh suku bangsa, mungkin sebagian saja, bahwa padsa umumnya menempatkan "harmonisasi" lebih utama, agar keseimbangan hidup lebih terpelihara. Sikap kompetitif-nya tidak rasional, tetapi pendekatan simbolik dengan menyertakan perasaan. Cukup dimengerti mempunyai kemampuan adaptasi, sedang dinamikanya terlihat pada kemampuan asimilasi dan daya serapnya tinggi yang dating dari sekitarnya.

\section{IV}

Uraian singkat dan sederhana ini, dimaksudkan untuk membuka dialog budaya dalam menemukan konsep untuk pembangunan kebudayaan nasional. Masyarakat transisi seperti halnya Indonesia sekarang ini, antara inovasi dan kompetisi sedang inter play dan mungkin tidak akan ketemu atau menemukan ujung yang diharapkan membawa kemajuan yang diharapakan. Kompetisi 
lebih banyak terjadi berputar-putar pada pemenuhan kebutuhan dan kepentingan sesaat, sementara inovasi berjalan lambat, karena terpengaruh oleh golakan persaingan. Komponen Sosial yang berada pada gelora kompetitif, adalah dari kalangan pemimpin organisasi, elit Sosial, pemuka masyarakat, bahkan mereka dari kalangan bawah yang memanfaatkan kesempatan kompetitif tersebut.

Inovasi dan kompetitif didekati dari segi kebudayaan, oleh karena keduanya merupakan hal yang mendasar dari gejala kemanusiaan yang kadang kala muncul sebagai gejala Sosial. Keduanya pula dapat memacu kemajuan dan modernisasi, jika diberangi dan didukung oleh kondisi Sosial.

Modal Sosial tampak dalam keseharian : seperti sifat kekeluargaan, sifat saling menolong Bantu, membantu, kesetiakawanan Sosial, koperatif saling paercaya antara sesama, semuanya itu tampil dalam prilaku dan tindakan Sosial. Watak dan karakter Sosial, terlihat pada sifat dan sikap sebagai : memiliki rasa malu atau "SIRI" (shamed culture), rasa bersalah (guilt culture), rasa bangga dan emosi keagamaan yang tinggi. Terapan kearifan local dalam modal Sosial adalah menggali dan memanfaatkan untuk : melindungi masyarakat miskin dan bermasalah, membangun kesertaan masyarakat dalam organisasi Sosial, mengendalikan konflik dan kekerasan, memelihara sumber daya alam dan Sosial. Kearifan local turun dari pengetahuan budaya local yang membentuk kearifan individu (orang) atau kelompok individu guna mengelola kehidupannya dari generasi ke generasi. Kearifan local tercakup berbagai mekanisme adaptif dan cara-cara untuk bersikap, berprilaku, dan bertindak kedalam tatanan Sosial.

Dimensi kearifan local adalah : mekanisme pengambilan keputusan, keterampilan local, sumberdaya local, dan tipe solidaritas Sosial. Perwujudannya tampak pada kecerdasan local yang ditransfer pada daya cipta, inovatif dan kreatifas untuk kemandirian local. Kearifan local mengambil sukma dan semangat dari nilai-nilai budaya yang telah disepakati secara Sosial. Kearifan local adalah suatu kondisi matang dan mantap yang terjadi dalam modal Sosial, biasanya dimiliki individu yang telah mengambil sukma masyarakatnya, itulah yang disebut indigenouse local, yaitu pribumi local.

\section{PEMANFAATAN MODAL BUDAYA DAN MODAL SOSIAL DALAM GERAKAN NASIONAL UNTUK KEBANGKTAN BUDAYA DALAM PEMBANGUNAN BANGSA KE DEPAN}

\begin{tabular}{|c|c|}
\hline MODAL BUDAYA (CULTURE CAPITAL) & MODAL SOSIAL (SOCIAL CAPITAL) \\
\hline $\begin{array}{l}\text { 1. Pengetahuan Lokal (Lokal Knowledge) } \\
\text { a. Hukum dan hukum adapt serta aturan yang menjadi } \\
\text { pedoman perilaku, sifat dan sikap dalam tindakan sosial } \\
\text { bagi suku bangsa tertentu atau kelompok, baik kecil } \\
\text { maupun kelompok besar. } \\
\text { b. Aturan dan peraturan yang bersumber dari nilai adat dan } \\
\text { agama pada lokal tertentu, ditaati dan terwujud dalam } \\
\text { perilaku anggota masyarakat. } \\
\text { c. Cita dan citra serta struktur yang diperoleh secara warisan } \\
\text { social dari hasil adaptasi tiap generasi. Hal itu bersumber } \\
\text { dari mitologi, legenda dan cerita rakyat. } \\
\text { Kearifan Lokal (Lokal Wisdom) } \\
\text { a. Karifan ini turun dari pengetahuan budaya lokal yang } \\
\text { membentuk kearifan individu atau sekelompok individu } \\
\text { guna mengelola kehidupan-nya dari generasi ke generasi. } \\
\text { Kearifan lokal tercakup berbagai mekanisme adaptif dan } \\
\text { cara-cara untuk bersikap, berperilaku dan bertindak ke } \\
\text { dalam tatanan sosial. } \\
\text { c. Dimensi kearifan lokal adalah; mekanisme pengambilan } \\
\text { keputusan; keterampilan lokal; sumber daya lokal; tipe } \\
\text { solidaritas sosial. } \\
\text { d. Perwujudannya tampak pada kecer-dasan lokal yang } \\
\text { ditransfer pada daya cipta, inovatif dan kreatifitas untuk } \\
\text { kemandirian lokal. } \\
\text { e. Kearifan lokal mengambil sukma dan semangat dari nilai- } \\
\text { nilai budaya yang telah disepakati secara sosial. } \\
\text { f. Local wisdom adalah suatu kondisi matang dan mantap } \\
\text { yang terjadi dalam masyarakat tertentu, biasanya dimiliki } \\
\text { oleh individu-individu yang mengambil alih sukma } \\
\text { masyarakat-nya, itulah yang disebut Indigenous Lokal yaitu } \\
\text { pribumi lokal. }\end{array}$ & $\begin{array}{l}\text { 1. Modal soaial secara luas terdiri atas norma-norma sosial dan } \\
\text { jaringan hubungan antara individu dan kelompok. Dalam norma } \\
\text { jaringan itu, terlihat aksi sosial dan mitra yang saling } \\
\text { mengukuhkan dan menguntungkan. } \\
\text { 2. Tenunan jaringan sosial itu atas dasar aturan dan peraturan, } \\
\text { sehingga tampak adanya sistem-sistrem yang pada bentuknya } \\
\text { yang lebih abstrak adalah sebuah struktur sosial. } \\
\text { 3. Jaringan-jaringan kerja dengan aturan teretentu biasanya } \\
\text { berwujud sebuah lembaga sosial, di dalamnya terjadi tindakan } \\
\text { sosial dan iterksi antara individu dan kelompok untuk memenuhi } \\
\text { harapan, kebutuhan, kepentingan dan tujuan lembaga. } \\
\text { 4. Modal sosial berisi lembaga-lembaga sosial; etika sosial dan } \\
\text { etika lingkungan. Kearifan lokal merupakan bagian sempit dari } \\
\text { modal sosial, sedang etos sosial sebagai sifat, sikap, watak dan } \\
\text { karakter sosial sesuai world Vieuw masyarkat lokal tersebut. } \\
\text { 5. Modal sosial tampak dalam keseharian, seperti; sifat } \\
\text { kekeluargaan, sifat saling menolong, bantu-membantu; kesetia- } \\
\text { kawanan sosial; bentuk-bentuk koperatif; saling percaya antar } \\
\text { sesama; semua tampak dalam perilaku dan tindakan sosial. } \\
\text { 6. Watak dan karakter sosial, terlihat pada sifat dan sikap sebagai; } \\
\text { memiliki rasa malu; rasa bersalah, rasa bangga dan emosi } \\
\text { keagamaan yang tinggi. } \\
\text { 7. Terapan kearifan lokal dalam modal sosial adalah menggali dan } \\
\text { memanfaatkannya untuk; melindungi masyarakat miskin dan } \\
\text { bermasalah; membangun kesetaraan masyarakat dalam organisasi } \\
\text { sosial; mengendalikan konflik dan kekerasan; memelihara } \\
\text { sumber daya alam dan sosial. }\end{array}$ \\
\hline
\end{tabular}




\section{KEPUSTAKAAN}

Abdulla, Taufik. Korupsi, Kolusi, dan Nepotisme; Sebuah Pendekatan Kultural, dalam Edy Suandy Hamid (ed), Menyikapkan Korupsi, Kolusi dan Nepotisme di Indonesia. Yogyakarta: Adity Media, 1999.

Geertz, E. The Interpretation of Culture, New York: Basic Book Inc, 1973,

Goodenough, W. Culture Language and Society. Reading, MA: Addison Wesley M. Pub. No. 7, 1971.

Koentjaraningrat Rintangan-rintangan Mental Dalam Pembangunan Ekonomi Indonesia. Jakarta: Bhratara, 1969.

Kluckhohn, C. Mirror For Man. USA: Wittlesey House, 1949.

Kleden, Ignas. Sikap Ilmiah dan Kritik Kebudayaan. Jakarta: LP3ES, 1987.

Kun, Thomas S. The Structure of Scidentific Revolution. Terjemahan Tjun Surjaman dengan judul Peran Paradigma dalam Revolusi Sains. Bandung: Remaja Rosdakarya, 1962.

Soedjatmoko. Dimensi Manusia dalam Pembangunan. Jakarta: LP3ES, 1984. 